\title{
Analyses of stomach contents and stable isotopes reveal food sources of estuarine detritivorous fish in tropical/subtropical Taiwan
}

\author{
Hsing-Juh Lin ${ }^{\mathrm{a}, \mathrm{b}, *}$, Wen-Yuan Kao ${ }^{\mathrm{c}}$, Ya-Ting Wang ${ }^{\mathrm{a}}$ \\ ${ }^{a}$ Department of Life Sciences, National Chung Hsing University, Taichung 402, Taiwan, ROC \\ ${ }^{\mathrm{b}}$ Institute of Marine Environmental Chemistry and Ecology, National Taiwan Ocean University, Keelung 202, Taiwan, ROC \\ ${ }^{\mathrm{c}}$ Department of Life Science, National Taiwan University, Taipei 106, Taiwan, ROC
}

Received 3 August 2006; accepted 16 February 2007

Available online 12 April 2007

\begin{abstract}
Detritivorous fish generally refers to fish that primarily ingest unidentified organic detritus. We analyzed stomach contents in combination with stable isotopes to trace and compare the food sources of the large-scale mullet Liza macrolepis and other detritivorous fish species in subtropical mangrove creeks and a tropical lagoon in Taiwan. The volume of organic detritus always contributed $>50 \%$ of the stomach content of $L$. macrolepis in the two habitats. However, consumed items were distinct between the two habitats and corresponded to the types in which they reside. The consumed items in the lagoon were more diverse than those observed in the mangroves. In the mangroves, the diet composition of $L$. macrolepis was primarily determined by season, not by body size. In the lagoon, there were no clear seasonal or size-dependent grouping patterns for the diet composition. There were significant seasonal and spatial variations in $\delta^{13} \mathrm{C}$ and $\delta^{15} \mathrm{~N}$ values of potential food sources and $L$. macrolepis. However, neither $\delta^{13} \mathrm{C}$ nor $\delta^{15} \mathrm{~N}$ values of L. macrolepis were correlated with fish body size. Joint analyses of stomach contents and stable isotopes indicated that benthic microalgae on sediments were the most important assimilated food in both seasons for the dominant detritivorous fish in the mangroves, whereas a greater reliance on microalgal and macroalgal periphyton on oyster-culture pens was observed in the lagoon. Mangrove and marsh plants and phytoplankton, which are mostly locally produced within each habitat, were of minor importance in the assimilated food.
\end{abstract}

(C) 2007 Elsevier Ltd. All rights reserved.

Keywords: $\delta^{13} \mathrm{C} ; \delta^{15} \mathrm{~N}$; stomach contents; tropical lagoon; mangroves; periphyton

\section{Introduction}

Many estuarine fish are detritivores, which generally refers to fish that primarily ingest unidentified organic detritus (Darnell, 1961; Yáñez-Arancibia, 1976). In estuaries, detritivory:herbivory ratios are often high when compared to those of other waters (Lin et al., 2001), suggesting that in such environments, organisms are more dependent on organic detritus than directly on plants. The high efficiency of fishery yields (Nixon

\footnotetext{
* Corresponding author. Department of Life Sciences, National Chung Hsing University, Taichung 402, Taiwan, ROC.

E-mail address: hjlin@dragon.nchu.edu.tw (H.-J. Lin).
}

et al., 1986) has led researchers to assume that a large proportion of estuarine fish are detritivores, which primarily consume the abundant organic detritus and directly convert into fish production (Mann, 1988). However, estuaries are often characterized by diverse plant communities and complex origins for the abundant organic detritus they contain. We still do not know food sources of detritivorous fish in estuaries.

Natural stable isotope analyses have been used to trace food sources of carnivorous fish in estuaries. Using $\delta^{13} \mathrm{C}$, Hughes and Sherr (1983) found that fish in salt marshes were most closely linked to the marsh plant Spartina and benthic algae. Rodelli et al. (1984) found that gobies in mangrove creeks obtained carbon from mangrove trees. Sullivan and Moncreiff 
(1990) measured $\delta^{13} \mathrm{C}$ and $\delta^{15} \mathrm{~N}$ and found that the food sources for marsh fish were benthic and planktonic algae. Using $\delta^{13} \mathrm{C}$ and $\delta^{34} \mathrm{~S}$, Stribling and Cornwell (1997) found that $\mathrm{C}_{3}$ plants were of greater importance in the assimilated diets of carnivorous fish in oligohaline wetlands. Combining $\delta^{13} \mathrm{C}$, $\delta^{15} \mathrm{~N}$, and $\delta^{34} \mathrm{~S}$ measurements, Kwak and Zedler (1997) found that Spartina was the major organic matter source for estuarine fish, whereas macroalgae and microalgae supported fish in a lagoon lacking Spartina. Deegan and Garritt (1997) found that terrestrial organic matter was of minor importance in estuarine food webs. Wainright et al. (2000) found that macrophytes and benthic microalgae were significant components of the diet of Fundulus heteroclitus in salt marshes. It appears that food sources of carnivorous fish in estuaries are very diverse, which might have been attributable to the prey items consisting of a variety of feeding groups and different habitat types. There has been no study to trace the food sources of detritivorous fish in estuaries.

Temporal and spatial variabilities of stable isotope ratios within all organic matter pools are often high (Stephenson et al., 1984; Cloern et al., 2002). These variabilities may obscure any source-specific isotopic signatures, confounding the application of stable isotopes for tracing trophic linkages from primary producers to consumers. Stomach content analyses can provide a taxonomic resolution of food that may be difficult to achieve by stable isotope analyses. Peterson (1999) suggested that stable isotope analyses are most effectively used in combination with other techniques such as stomach content analyses. The large-scale mullet Liza macrolepis (family Mugilidae) are the most abundant detritivorous fish in estuaries and mangroves along the western coast of Taiwan (Lin and Shao, 1999; Kuo et al., 2001). In this study, we examined stomach contents in combination with stable carbon and nitrogen isotopes to trace and compare the food sources of $L$. macrolepis and other dominant detritivorous fish species in two different habitats: subtropical mangrove creeks draining mangroves and marshes, and a tropical lagoon with fewer vascular plants but abundant phytoplankton and periphyton on oyster-culture pens (Fig. 1). We also examined if differences existed between the food sources of L. macrolepis in the dry and wet seasons.

\section{Materials and methods}

\subsection{Study sites}

One of the study sites was situated in mangrove creeks of the Guandu wetlands $\left(25^{\circ} 7^{\prime} \mathrm{N}, 121^{\circ} 27^{\prime} \mathrm{E}\right)$, which is located in an estuary at the confluence of the Danshuei and Keelung Rivers in subtropical northern Taiwan (Fig. 1). These rivers flow through Taipei City of six million people and receive nutrient inputs from treated and untreated domestic sewage and agricultural effluents. Climatic data derived from a local weather station of the Central Weather Bureau of Taiwan from 1971 to 2000 show that the mean air temperature ranged from $15.1{ }^{\circ} \mathrm{C}$ in January to $28.8^{\circ} \mathrm{C}$ in July. The mean annual and monthly precipitation values were 2120 and $177 \mathrm{~mm}$, respectively. The Guandu mangroves are composed of the mangrove Kandelia candel (ca. $0.55 \mathrm{~km}^{2}$ ) and marshes containing the plants Brachiaria mutica, Clerodendrum inerme, Cyperus malaccensis, Phragmites communis, and Typha angustifolia (ca. $0.57 \mathrm{~km}^{2}$ ). They are subjected to a semidiurnal tidal regime with a tidal amplitude of about $1-2 \mathrm{~m}$. The creeks are about $5 \mathrm{~m}$ wide with water about $0.5 \mathrm{~m}$ deep covering a thick layer of sandy-silt sediment at low tide. Salinities of the overlying waters ranged from 7 to 12 psu at low tide and might reach $25 \mathrm{psu}$ at high tide. Water column chlorophyll $a$ remained at $5 \mathrm{mg} \mathrm{m}^{-3}$, but could reach $40 \mathrm{mg} \mathrm{m}^{-3}$ in summer (authors' unpubl. data). Concentrations of dissolved inorganic nitrogen (DIN) in the water column were high $(34-195 \mu \mathrm{M})$.

The other study site was situated in Tapong Bay $\left(22^{\circ} 27^{\prime} \mathrm{N}\right.$, $120^{\circ} 26^{\prime} \mathrm{E}$ ), which is a tropical lagoon in southern Taiwan, and has only one tidal inlet connecting it to the sea. Tapong Bay has a $4.44-\mathrm{km}^{2}$ surface area with a mean depth of $2.2 \mathrm{~m}$ at low tide (Fig. 1). It is primarily subjected to semidiurnal tides with a tidal range of $1.0 \mathrm{~m}$. Since no large river flows into the lagoon, the salinity remains high (25-34 psu). Climatic data from 1971 to 2000 of a nearby weather station show that the mean air temperature ranged from $18.8^{\circ} \mathrm{C}$ in January to $28.9^{\circ} \mathrm{C}$ in July. Despite a mean annual precipitation of $1785 \mathrm{~mm}$, there are distinct dry and wet seasons. During the wet season of May-September, mean monthly precipitation frequently exceeds $200 \mathrm{~mm}$, and in October-April, mean monthly precipitation normally does not exceed $50 \mathrm{~mm}$. Tapong Bay is lined by the mangrove Avicennia marina and marshes composed of Clerodendrum inerme, Derris laxiflora, and Excoecaria agallocha. The lagoon is densely covered by thousands of oyster-culture pens. Since the lagoon water is often turbid (light extinction $>1.0 \mathrm{~m}^{-1}$ ) and the bottom water in the inner lagoon possibly becomes hypoxic (Hung and Hung, 2003), no rooted macrophytes were observed in the lagoon. Benthic microalgae and macroalgal periphyton on oyster-culture pens, together with phytoplankton, dominate this lagoon. Water column chlorophyll $a$ averages $8.4 \mathrm{mg} \mathrm{m}^{-3}$ in summer and $5.8 \mathrm{mg} \mathrm{m}^{-3}$ in winter (Su et al., 2004). Although there was a wide range of water column DIN concentrations $(0.46-23.2 \mu \mathrm{M})$, the loads of DIN from surrounding aquaculture ponds were high (1.2 $\mathrm{mol} \mathrm{m}^{-2} \mathrm{yr}^{-1}$, Lin and Hung, 2004).

\subsection{Field collections}

Potential food sources, including sestonic particulate organic matter (SPOM), benthic microalgae (mainly diatoms, authors' pers. obs.), macroalgae, cyanobacteria, marsh plants, and mangrove leaves were collected at both sites. Different body sizes of Liza macrolepis were collected from both sites for analyses of stomach contents and stable isotopes to examine whether ontogenetic diet changes existed. Other dominant detritivorous fish species, including an Oreochromis hybrid (family Cichlidae), Pomacentrus taeniometopon (Pomacentridae), Scarus ghobban (Scaridae), Scatophagus argus (Scatophagidae), Siganus guttatus (Siganidae), and Valamugil cunnesius (Mugilidae), were also collected for stable isotope 

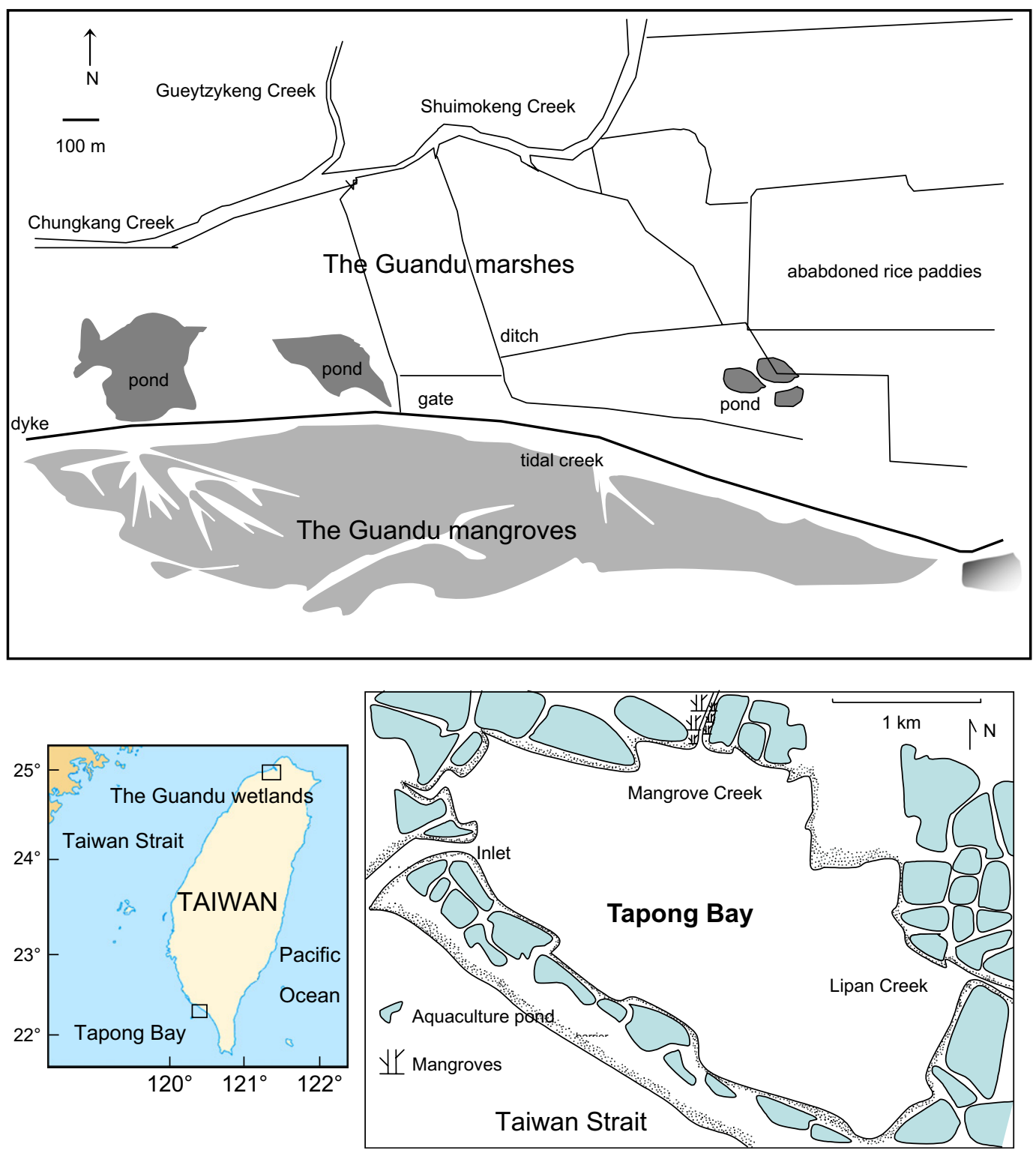

Fig. 1. The Guandu mangroves, Tapong Bay and their surrounding land uses.

analyses for comparisons. To characterize diet changes between the dry and wet seasons, samples were collected in January-March 2001 (the dry season) and July-August 2001 (the wet season).

For each sampling of SPOM, $20 \mathrm{~L}$ of water was taken $30 \mathrm{~cm}$ below the water surface at both flood and ebb tides. Upon returning to the laboratory, water samples were filtered onto precombusted glass fiber filters $(\mathrm{GF} / \mathrm{F})$ through a mesh opening diameter of $200 \mu \mathrm{m}$, and carbonate was removed by acidification with $1 \mathrm{~N} \mathrm{HCl}$. In the mangrove creeks, benthic microalgae appearing as a brown-colored layer on the surface of the sediments were sampled by scraping off $2 \mathrm{~mm}$ of the surface layer. Within $1 \mathrm{~h}$ of collection, the sediments were brought back to the laboratory where the microalgae were concentrated and separated from bulk sediments by a procedure modified from that described by Riera and Richard (1996). In the lagoon, benthic microalgae on oyster shells were washed off in distilled water using a toothbrush and were retained on precombusted glass fiber filters $(\mathrm{GF} / \mathrm{F})$ by sieving through a mesh with an opening diameter of $62 \mu \mathrm{m}$. Senescent leaves of mangrove and marsh plants in the mangrove creeks and macroalgal periphyton on oyster-culture pens in the lagoon were, respectively, collected and vigorously washed with distilled water to remove epiphytes and extraneous sediments. These samples of potential food sources were then freeze-dried and ground for stable isotope analyses.

Fish were collected using fyke nets. This fishing gear is a passive sampler designed to collect nekton in a depth range of $0.5-2.0 \mathrm{~m}$ and is composed of two fence nets $(15 \mathrm{~m}$ long and $1.5 \mathrm{~m}$ high, with a mesh opening diameter of $15 \mathrm{~mm}$ ) and a hoop-net (with a mesh opening diameter of $10 \mathrm{~mm}$ ). Fyke nets were set out and uplifted early in the morning (04:00) when most fish were feeding. For each captured fish, total length (TL) and fresh weight were recorded, and white 
muscle tissue and digestive tract were removed and frozen for later analyses of stomach content and stable isotopes, respectively. Because of budget constraints and integrative nature of stable isotopes, fish samples subjected to examination of stomach content were randomly assigned for stable isotope analyses.

\subsection{Stomach content analyses}

Stomach contents were sorted taxonomically and counted using a light microscope at $400 \times$ after sedimentation on a slide. Two transects (about 100 fields) were scanned on a slide. The frequency of occurrence method was employed by recording the number of stomachs containing one or more individuals of each consumed item, and the total was expressed as a percentage of the total number of stomachs examined $(\mathrm{FO} \%)$. The volume of a consumed item was then determined by squashing the stomach contents on a slide to a uniform depth and the area of the squash was measured. The volume of a consumed item taken by a fish population was given as a percentage of the total volume of the stomach content $(V \%)$. Consideration of both volumetric percentage and frequency of occurrence percentage for a consumed item can provide an indication of the homogeneity of feeding within a fish population (Hyslop, 1980). Fish samples with empty stomachs were excluded from this analysis.

\subsection{Stable isotope analyses}

We analyzed $\delta^{13} \mathrm{C}$ and $\delta^{15} \mathrm{~N}$ of white muscle tissues of the fish. Each fish sample was treated individually. $\delta^{13} \mathrm{C}$ values were used to determine carbon sources. $\delta^{15} \mathrm{~N}$ values were analyzed as a secondary tracer to indicate the trophic position. Tissues were freeze-dried and then ground. Because the ${ }^{13} \mathrm{C}$ content of lipids may be depleted and this can affect ecological interpretations (Kling et al., 1992), samples were washed in a 2:1:0.8 methanol:chloroform:water solution for $2 \mathrm{~h}$ (Bligh and Dyer, 1959), and then treated with $1 \mathrm{~N} \mathrm{HCl}$ to remove lipids and carbonates (Boutton, 1991). The $\delta^{13} \mathrm{C}$ and $\delta^{15} \mathrm{~N}$ values of samples were determined with a continuous-flow isotope ratio mass spectrometer (Finnigan delta $S$ ) coupled with an elemental analyzer (Carlo Erba NA 1500 NCS). Because lipid extraction and acidification have been found to alter tissue $\delta^{15} \mathrm{~N}$ (Pinnegar and Polunin, 1999; Sweeting et al., 2006), chemically treated and untreated samples were run for $\delta^{13} \mathrm{C}$ and $\delta^{15} \mathrm{~N}$, respectively. The precision of the measurements was $\pm 0.1 \%$ for both the stable carbon and nitrogen isotope analyses. Stable isotope data were reported as the relative difference between ratios of a sample and standards in standard notation as: $\delta X(\%)=\left[\left(R_{\text {sample }} / R_{\text {standard }}\right)-1\right] \times 10^{3}$, where $R={ }^{13} \mathrm{C} /{ }^{12} \mathrm{C}$ or ${ }^{15} \mathrm{~N} /{ }^{14} \mathrm{~N}$. $\delta^{13} \mathrm{C}$ or $\delta^{15} \mathrm{~N}$ is the per-mil $(\%)$ deviation of that sample from the recognized isotope standard, i.e., PeeDee Belemnite (PDB) limestone for $\delta^{13} \mathrm{C}$ and atmospheric $\mathrm{N}_{2}$ for $\delta^{15} \mathrm{~N}$ (Gonfiantini et al., 1995). DeNiro and Epstein (1978) found that an animal is on average enriched in $\delta^{13} \mathrm{C}$ by about $1 \%$ relative to its diet. Minagawa and Wada (1984) and Post (2002) showed that the mean enrichment in $\delta^{15} \mathrm{~N}$ at a single feeding process is $3.4 \%$. The dual-isotope, multiplesource mixing model (Ben-David et al., 1997), was then used as an index of relative contribution of each source to the assimilated diet of the dominant detritivorous fish species in each habitat.

\subsection{Statistical analyses}

In order to reveal seasonal and ontogenetic patterns in the diet of Liza macrolepis in each habitat, changes in the composition of stomach contents were studied at each site using multivariate analyses in the PRIMER (vers. 5.2) computer package (Clarke and Gorley, 2001). Bray-Curtis coefficient was used to produce a similarity matrix of volumetric composition of stomach contents between any two samples. Before calculating the similarity coefficients, the volumetric percentage of each food item was square root-transformed using the power transformations (Clarke and Warwick, 1994) to downweight the effects of dominant consumed items. The similarity matrix was classified by hierarchical agglomerative clustering using the unweighted pair group mean arithmetic (UPGMA) linking method. A Chi-square test was then used to test differences in volumetric composition of consumed items of $L$. macrolepis between the dry and wet seasons.

For each site, Spearman's rank correlations $\left(r_{\mathrm{s}}\right)$ between $\delta^{13} \mathrm{C}$ and $\delta^{15} \mathrm{~N}$ and total length of Liza macrolepis were computed using data from individual fish to examine whether ontogenetic diet changes existed. A two-way fixed ANOVA model was then used to evaluate whether $\delta^{13} \mathrm{C}$ and $\delta^{15} \mathrm{~N}$ values of potential food sources and of L. macrolepis differed between the two seasons (the dry and wet seasons) or the two sites (the mangrove creeks and the tropical lagoon). Before the analyses, the data were tested by the power transformations for normality and homogeneity of variance assumptions (Clarke and Warwick, 1994). These univariate statistical calculations were produced using the SAS system (vers. 8.2).

\section{Results}

\subsection{Stomach content analyses}

In the Guandu mangroves and Tapong Bay, the sampled body sizes of Liza macrolepis ranged 39-242 mm, which are generally beyond its maturity size of $40 \mathrm{~mm}$ total length (Froese and Pauly, 2006). In the Guandu mangroves, classification of the volumetric composition (V\%) of consumed items from each individual fish of $L$. macrolepis separated the stomach contents into two major categories (D and $\mathrm{W}$ ) at a similarity level of $65 \%$ (Fig. 2a). Category D contained stomach contents mainly from the dry season, while category $\mathrm{W}$ was composed of samples from the wet season. The grouping patterns showed that the diet composition of L. macrolepis in the Guandu mangroves was primarily determined by season, not by body size.

In the mangroves, unidentified organic detritus, epipelic diatoms (mainly Navicula and Nitzschia, Round et al., 1990), and vascular plants were the most frequently consumed items 
a
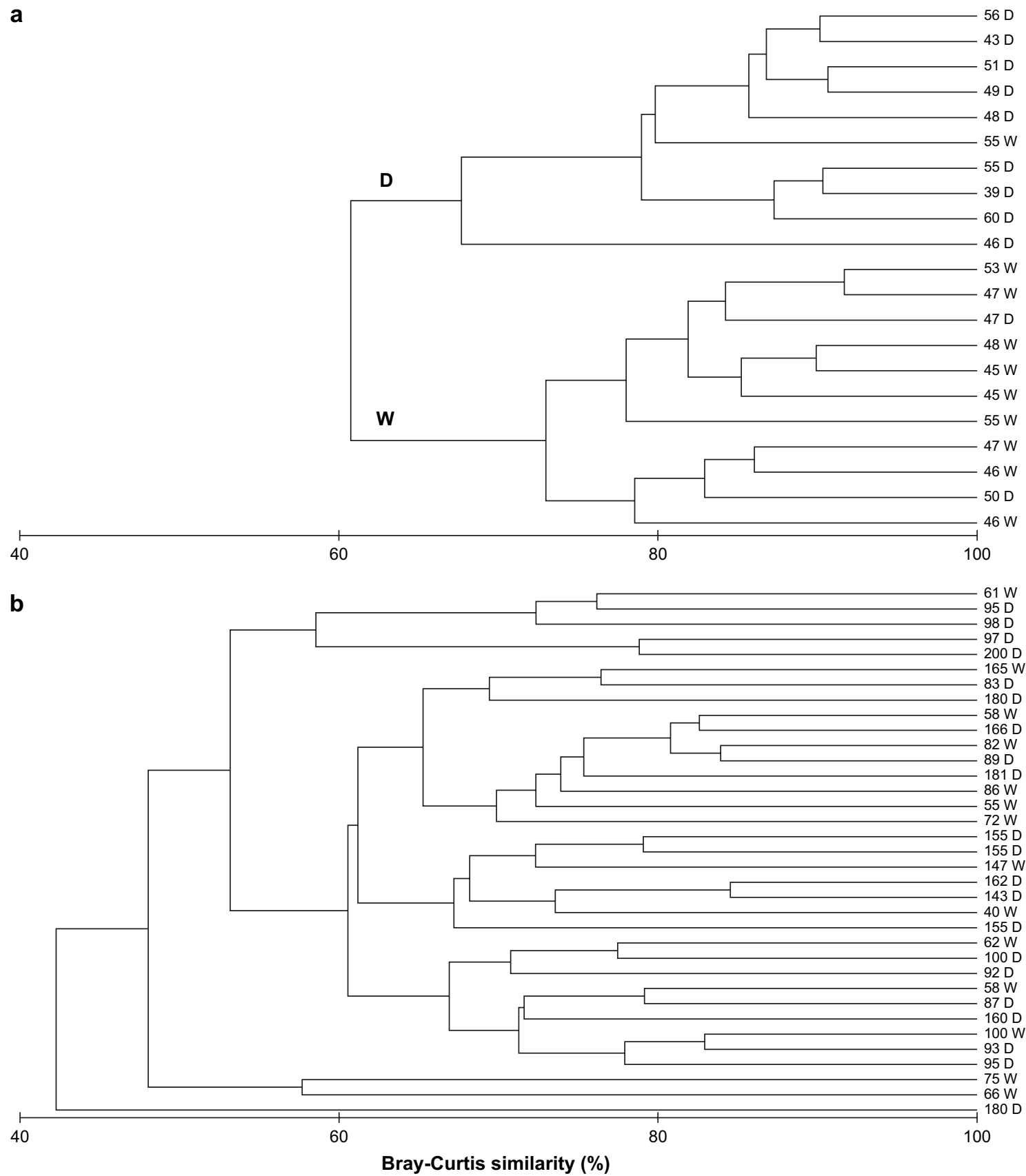

Fig. 2. Classification of the diet composition of individual fish of Liza macrolepis with different total lengths (in mm) collected from (a) the Guandu mangroves and (b) Tapong Bay in the dry (D) and wet (W) seasons.

(FO\%) in the stomach contents of L. macrolepis (Table 1) in both seasons. Volumetric compositions $(V \%)$ of the stomach contents significantly differed between the two seasons (Chisquare test, $p<0.001)$. The contributions of organic detritus and vascular plants were co-dominant in the dry season, whereas in the wet season, the percentages of organic detritus and diatoms increased, while that of vascular plants decreased.

In Tapong Bay, there were no clear seasonal or sizedependent grouping patterns for volumetric compositions of the stomach contents of Liza macrolepis (Fig. 2b). Unidentified organic detritus, macroalgae, and epipelic diatoms (mainly Navicula) were the dominant consumed items and together contributed $>85 \%$ to the total volume (Table 1 ). Benthic invertebrates (snails and amphipods) were also observed in the stomach contents, but the $V \%$ values were small.

Consumed items in the stomach contents of Liza macrolepis in the tropical lagoon were more diverse than those observed in the mangrove creeks (Table 1). In addition to the consumed items recorded in the mangroves, dinoflagellates, benthic invertebrates, and fungi were recorded from fish in the lagoon. Volumetric compositions of consumed items differed between the two habitats (Chi-square test, $p<0.001$ ). In the lagoon, the contribution of macroalgae and diatoms was greater, but that of vascular plants was lower. 
Table 1

Frequency of occurrence $(\mathrm{FO} \%)$ and percentage by volume $(V \%)$ of consumed items in the diets of Liza macrolepis in the Guandu mangroves and Tapong Bay collected in the wet and dry seasons of 2001. Sample size ( $n$ ) refers to the total number of stomachs examined; also given under the size class are the means $\pm \mathrm{SE}$, the range of total lengths, and the percentages of stomachs that were empty

\begin{tabular}{|c|c|c|c|c|}
\hline Site/season & Size class & Item & $\mathrm{FO} \%$ & $V \%$ \\
\hline \multicolumn{5}{|c|}{ The Guandu mangroves } \\
\hline \multirow[t]{5}{*}{ Dry season } & $n=36$ & Cyanobacteria & 18.2 & 0.2 \\
\hline & $49.5 \pm 1.8 \mathrm{~mm}$ & Diatoms & 90.9 & 4.4 \\
\hline & $39-60 \mathrm{~mm}$ & Macroalgae & 9.1 & 0.1 \\
\hline & $53 \%$ empty & Vascular plants & 100 & 43.2 \\
\hline & & Organic detritus & 100 & 52.1 \\
\hline \multirow[t]{5}{*}{ Wet season } & $n=32$ & Cyanobacteria & 20.0 & 0.3 \\
\hline & $48.7 \pm 1.3 \mathrm{~mm}$ & Diatoms & 100 & 8.1 \\
\hline & $43-49 \mathrm{~mm}$ & Macroalgae & 60.0 & 0.3 \\
\hline & $41 \%$ empty & Vascular plants & 80.0 & 11.2 \\
\hline & & Organic detritus & 100 & 80.1 \\
\hline \multirow[t]{8}{*}{ Tapong Bay } & $n=72$ & Cyanobacteria & 51.4 & 2.9 \\
\hline & $111.2 \pm 7.7 \mathrm{~mm}$ & Diatoms & 100 & 10.8 \\
\hline & $40-200 \mathrm{~mm}$ & Dinoflagellates & 45.7 & 0.8 \\
\hline & $29 \%$ empty & Macroalgae & 88.6 & 19.1 \\
\hline & & Fungi & 14.1 & 0.2 \\
\hline & & Vascular plants & 54.3 & 5.3 \\
\hline & & Benthic invertebrates & 34.1 & 4.5 \\
\hline & & Organic detritus & 100 & 56.1 \\
\hline
\end{tabular}

\subsection{Stable isotope analyses}

$\delta^{13} \mathrm{C}$ and $\delta^{15} \mathrm{~N}$ values of potential food sources in the Guandu mangroves and Tapong Bay showed clear spatial and seasonal variations (Tables 2 and 3 ). Generally, $\delta^{13} \mathrm{C}$ and $\delta^{15} \mathrm{~N}$ values of the same functional groups were more enriched in the tropical lagoon than in the mangroves (Table 4). At both sites, $\delta{ }^{13} \mathrm{C}$ values of SPOM were more enriched in the dry season than in the wet season. However, there was an interactive effect of site and season on $\delta^{13} \mathrm{C}$ values of benthic microalgae, which were more enriched in the wet season in Tapong Bay, but were more enriched in the dry season in the mangroves. $\delta^{15} \mathrm{~N}$ values of benthic microalgae showed enrichment in the wet season at both sites.

Different species of detritivorous fish collected from each habitat in the same season generally had similar $\delta^{13} \mathrm{C}$ values (Tables 5 and 6). Size-dependent variations in $\delta^{13} \mathrm{C}$ (Spearman's rank correlation, $r_{\mathrm{s}}=-0.018$ and $p=0.96$ in the Guandu mangroves; $r_{\mathrm{s}}=-0.028, p=0.88$ in Tapong Bay) and $\delta^{15} \mathrm{~N}$ (Spearman's rank correlation, $r_{\mathrm{s}}=-0.379$, $p=0.25$ in the Guandu mangroves; $r_{\mathrm{s}}=-0.028, p=0.88$ in Tapong Bay) values of Liza macrolepis were not significant within the size range sampled in each habitat. Like spatial variations of potential food sources, $\delta^{13} \mathrm{C}$ and $\delta^{15} \mathrm{~N}$ values of $L$. macrolepis were also more enriched in Tapong Bay than in the Guandu mangroves (Table 4). In the mangroves, $\delta^{13} \mathrm{C}$ and $\delta^{15} \mathrm{~N}$ values were more enriched in L. macrolepis collected in the dry season than in the wet season, although the interactive effect of site and season on $\delta^{13} \mathrm{C}$ was marginally significant (two-way ANOVA, $p=0.10$ ).
Table 2

Summary of $\delta^{13} \mathrm{C}(\%)$ and $\delta^{15} \mathrm{~N}(\%)$ of potential food sources collected in the Guandu mangroves. Means $\pm \mathrm{SE}$ and the individual number measured $(n)$ are shown below. SPOM, sestonic particulate organic matter

\begin{tabular}{|c|c|c|c|}
\hline Season & Food source $(n)$ & $\delta^{13} \mathrm{C}(\%)$ & $\delta^{15} \mathrm{~N}(\%)$ \\
\hline \multirow[t]{11}{*}{ Dry } & $\mathrm{C}_{4}$ marsh plants & & \\
\hline & Cyperus malaccensis (1) & -12.7 & 6.3 \\
\hline & Brachiaria mutica (1) & -12.9 & 6.3 \\
\hline & $\mathrm{C}_{3}$ marsh plants & & \\
\hline & Phragmites communis (2) & $-27.4 \pm 0.6$ & $5.6 \pm 1.5$ \\
\hline & Clerodendrum inerme (1) & -26.9 & 6.7 \\
\hline & Typha angustifolia (1) & -28.1 & 4.5 \\
\hline & Mangrove Kandelia candel (1) & -29.6 & 7.2 \\
\hline & Benthic microalgae (3) & $-22.5 \pm 0.1$ & $2.3 \pm 0.2$ \\
\hline & SPOM at flood tide (2) & $-23.6 \pm 0.1$ & $2.7 \pm 0.2$ \\
\hline & SPOM at ebb tide (2) & $-24.7 \pm 0.1$ & $-0.5 \pm 0.1$ \\
\hline \multirow[t]{10}{*}{ Wet } & $\mathrm{C}_{4}$ marsh plants & & \\
\hline & Brachiaria mutica (1) & -13.6 & 6.2 \\
\hline & $\mathrm{C}_{3}$ marsh plants & & \\
\hline & Phragmites communis (1) & -26.9 & 1.4 \\
\hline & Clerodendrum inerme (1) & -27.9 & 5.8 \\
\hline & Typha angustifolia (1) & -29.1 & 4.4 \\
\hline & Mangrove Kandelia candel (1) & -28.2 & 6.8 \\
\hline & Benthic microalgae (2) & $-24.1 \pm 0.1$ & $3.4 \pm 0.3$ \\
\hline & SPOM at flood tide (2) & $-26.1 \pm 0.1$ & $-0.02 \pm 0.01$ \\
\hline & SPOM at ebb tide (2) & $-27.1 \pm 0.1$ & $-2.4 \pm 0.1$ \\
\hline
\end{tabular}

According to the trophic fractionation of $\mathrm{C}$ and $\mathrm{N}$ (DeNiro and Epstein, 1978; Minagawa and Wada, 1984; Post, 2002), in the Guandu mangroves, data points of the $\delta^{13} \mathrm{C}$ vs. $\delta^{15} \mathrm{~N}$ plots for the dry (Fig. 3a) and wet seasons (Fig. 3b) appeared that benthic microalgae on sediments and a mixture of $\mathrm{C}_{4}$ marsh plants and SPOM were the primary food sources for the dominant detritivorous fish. However, $\delta^{13} \mathrm{C}$ values of benthic microalgae and detritivorous fish shifted in the same direction seasonally, from higher values in the dry season to lower values in the wet season, whereas a slight shift occurred on the values of $\mathrm{C}_{4}$ marsh plants. In addition, stomach content analyses showed that the dominant genera of diatoms in the diets of Liza macrolepis were epipelic Navicula and Nitzschia. This suggested that benthic microalgae were the main food sources for the dominant detritivorous fish. The mixing model further indicated that the relative contribution of benthic microalgae to the assimilated food averaged $45 \%$.

In Tapong Bay, data points of the $\delta^{13} \mathrm{C}$ vs. $\delta^{15} \mathrm{~N}$ plots for the dry (Fig. 4a) and wet seasons (Fig. 4b) indicated a great reliance of the dominant detritivorous fish on benthic microalgae and macroalgal periphyton on oyster-culture pens. The mixing model showed that the summed percentage of benthic microalgae and macroalgal periphyton in the assimilated food was consistently $>55 \%$.

\section{Discussion}

$\mathrm{C}_{3}$ marsh plants and SPOM collected from Tapong Bay and the Guandu mangroves showed a clear spatial variation in $\delta^{13} \mathrm{C}$ 
Table 3

Summary of $\delta^{13} \mathrm{C}(\%)$ and $\delta^{15} \mathrm{~N}(\%)$ of potential food sources collected in Tapong Bay. Means $\pm \mathrm{SE}$ and the individual number measured $(n)$ are shown below. SPOM, sestonic particulate organic matter

\begin{tabular}{|c|c|c|c|}
\hline Season & Food source $(n)$ & $\delta^{13} \mathrm{C}(\%)$ & $\delta^{15} \mathrm{~N}(\%)$ \\
\hline \multirow[t]{14}{*}{ Dry } & $\mathrm{C}_{3}$ marsh plants & & \\
\hline & Clerodendrum inerme (1) & -23.7 & 9.9 \\
\hline & Excoecaria agallocha (1) & -25.5 & 10.1 \\
\hline & Derris laxiflora (1) & -27.6 & 1.4 \\
\hline & Mangrove Avicennia marina (1) & -26.3 & 5.6 \\
\hline & Macroalgal periphyton & & \\
\hline & Ceramium cimbricum (3) & $-10.6 \pm 0.1$ & $10.9 \pm 0.1$ \\
\hline & Chaetomorpha crassa (5) & $-11.4 \pm 0.7$ & $10.4 \pm 0.1$ \\
\hline & Enteromorpha intestinalis (30) & $-11.7 \pm 0.6$ & $11.1 \pm 0.1$ \\
\hline & Ulva fasciata (9) & $-11.3 \pm 0.7$ & $11.4 \pm 0.8$ \\
\hline & Ulva lactuca (22) & $-11.2 \pm 0.3$ & $11.0 \pm 0.2$ \\
\hline & Lyngbya majuscula (24) & $-12.7 \pm 0.6$ & $10.5 \pm 0.2$ \\
\hline & Benthic microalgae (3) & $-22.9 \pm 0.1$ & $11.6 \pm 0.1$ \\
\hline & SPOM at ebb tide (1) & -19.0 & 7.0 \\
\hline \multirow[t]{13}{*}{ Wet } & $\mathrm{C}_{3}$ marsh plants & & \\
\hline & Clerodendrum inerme (1) & -27.7 & 4.4 \\
\hline & Excoecaria agallocha (1) & -26.6 & 12.0 \\
\hline & Derris laxiflora (1) & -26.2 & 5.5 \\
\hline & Mangrove Avicennia marina (1) & -28.1 & 10.5 \\
\hline & Macroalgal periphyton & & \\
\hline & Enteromorpha intestinalis (12) & $-11.5 \pm 0.8$ & $10.2 \pm 0.4$ \\
\hline & Ulva fasciata (3) & $-10.4 \pm 0.3$ & $11.5 \pm 0.8$ \\
\hline & Ulva lactuca (2) & $-10.8 \pm 0.2$ & $10.6 \pm 0.1$ \\
\hline & Lyngbya majuscula (5) & $-14.9 \pm 1.9$ & $10.7 \pm 0.3$ \\
\hline & Benthic microalgae (2) & $-17.8 \pm 0.2$ & $12.7 \pm 0.2$ \\
\hline & SPOM at flood tide (1) & -23.4 & 5.4 \\
\hline & SPOM at ebb tide (1) & -23.5 & 7.1 \\
\hline
\end{tabular}

values, which were more enriched in the tropical lagoon than in the subtropical mangroves. A possible cause of this spatial pattern is the different sources of dissolved inorganic carbon between the two sites and isotopic fractionation by plants. The $\delta^{13} \mathrm{C}$ values of terrestrial and freshwater $\mathrm{C}_{3}$ plants or oligohaline phytoplankton have been shown to be more depleted than the values of marine benthic diatoms or phytoplankton along a salinity gradient in estuaries (e.g. Fry and Sherr, 1984; Hsieh et al., 2000). While Tapong Bay receives little riverine input, the Guandu mangroves are greatly influenced by the discharge of the Danshuei and Keelung Rivers and the ${ }^{13} \mathrm{C}$ signatures are thus more depleted. This is also evidenced by the clear seasonal patterns for the diet composition of Liza macrolepis from the mangroves, but not from the lagoon. Other possibility is water use efficiency of plants. Farquhar et al. (1989) found that there is a negative linear relationship between $\delta^{13} \mathrm{C}$ values of $\mathrm{C}_{3}$ leaves and the ratios of intercellular to ambient $\mathrm{CO}_{2}$ concentrations, implying that $\delta^{13} \mathrm{C}$ values can be used to indicate the long-term integrated water use efficiency of plants. The mean annual and monthly precipitation values were lower in Tapong Bay and were concentrated only within the 2-3 months of summer. In addition, since no large river flows into the lagoon, the salinity in the lagoon is remarkably higher than in the mangroves. It is likely that the enriched $\delta^{13} \mathrm{C}$ values of $\mathrm{C}_{3}$ marsh plants taken from the lagoon are due to less water being available and to the maintenance of a higher water use efficiency. Salinities of intertidal sediments taken from the mangroves were often higher than those of overlying water (Lin et al., 2003). This may also explain the higher $\delta^{13} \mathrm{C}$ values of $\mathrm{C}_{4}$ marsh plants and benthic microalgae on intertidal sediments taken from the Guandu mangroves in response to less water availability in the dry season.

In Tapong Bay, however, $\delta^{13} \mathrm{C}$ values of benthic microalgae and macroalgal periphyton on oyster-culture pens submerged in the water column were more enriched in the wet season than in the dry season. Finlay et al. (2002) observed that algal $\delta^{13} \mathrm{C}$ in riffles increased during the summer when $\mathrm{pH}$ was highest and $\mathrm{CO}_{2}$ was lowest in the water column. They also found a strong negative relationship between algal $\delta^{13} \mathrm{C}$ and water velocity in rivers. In Tapong Bay, productivity and biomass of phytoplankton and $\mathrm{pH}$ are greater in the wet season (Hung and Hung, 2003; Su et al., 2004). Therefore, the higher algal $\delta^{13} \mathrm{C}$ measured in the lagoon in the wet season may have been due to changes in $\mathrm{pH}$ or water turbulence resulting in changes in $\mathrm{CO}_{2}$ in the water column.

$\delta^{15} \mathrm{~N}$ values of terrestrial plants $\left(\mathrm{C}_{3}\right.$ and $\mathrm{C}_{4}$ marsh plants $)$ did not appear to be affected by site or season. Nevertheless, $\delta^{15} \mathrm{~N}$ values of algae and SPOM showed a significant spatial variation, which were more enriched in Tapong Bay than in the Guandu mangroves. This suggests that the heterogeneity of $\delta^{15} \mathrm{~N}$ values was relevant to $\mathrm{N}$ sources in the water column. $\delta^{15} \mathrm{~N}$ values have been useful in detecting anthropogenic $\mathrm{N}$ loading. $\delta^{15} \mathrm{~N}$ values are often high for nutrient inputs of sewage and aquaculture ponds but low for agricultural inputs (McClelland et al., 1997; Fry, 1999; Jones et al., 2001; Costanzo et al., 2003). In Tapong Bay, the loads of sewage DIN $\left(1.2 \mathrm{~mol} \mathrm{~m}^{-2} \mathrm{yr}^{-1}\right)$ from surrounding aquaculture ponds were high when compared to those in other estuaries and coastal lagoons (Lin and Hung, 2004). For the dominant periphyton species Ulva lactuca, Enteromorpha intestinalis, and Lyngbya majuscula in the lagoon, mean tissue $\mathrm{N}$ reached $4.1-6.5 \%$ dry wt., which is comparable to values of similar taxa found in other studies under enriched conditions (Kamer et al., 2001). Accordingly, the elevated $\delta^{15} \mathrm{~N}$ and $\% \mathrm{~N}$ of algae collected in Tapong Bay are indicative of sewage inputs from surrounding aquaculture ponds. The lower $\delta^{15} \mathrm{~N}$ values in the Guandu mangroves suggest that the Danshuei and Keelung Rivers receive both nutrient inputs from domestic sewage and agricultural effluents.

Mullet are often the dominant fish species in estuaries and coastal shallow waters worldwide. Food items reported in the stomach contents of mullet are primarily diatoms, macroalgae, and unidentified organic detritus (Odum, 1970; Yáñez-Arancibia, 1976; Chan and Chua, 1979). However, there is substantial heterogeneity in the relative importance of each item in the stomach contents. As a result, Odum (1970) and Chan and Chua (1979) considered mullet to be herbivores, whereas Yáñez-Arancibia (1976) reported that mullet are detritivores. In this study, consumed items in the stomach contents of Liza macrolepis were distinct between the two habitats and corresponded to the types in which they reside. In the Guandu 
Table 4

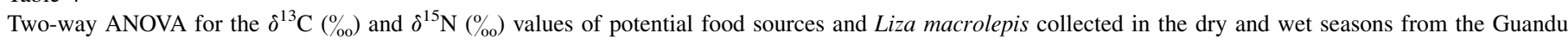
mangroves $(G)$ and Tapong Bay $(T)$. ${ }^{*} p<0.05$. SPOM, sestonic particulate organic matter

\begin{tabular}{|c|c|c|c|c|c|c|c|c|}
\hline \multirow[t]{2}{*}{ Source/fish } & \multicolumn{4}{|c|}{$\delta^{13} \mathrm{C}$} & \multicolumn{4}{|c|}{$\delta^{15} \mathrm{~N}$} \\
\hline & df & MS & $F$ & $p$ & df & MS & $F$ & $p$ \\
\hline \multicolumn{9}{|c|}{$C_{3}$ marsh plants } \\
\hline Site & 1 & 6.78 & 4.97 & $0.05^{*}$ & 1 & 17.9 & 1.77 & 0.21 \\
\hline Season & 1 & 2.36 & 1.74 & 0.21 & 1 & 2.30 & 0.18 & 0.68 \\
\hline Site $\times$ season & 1 & 0.40 & 0.28 & 0.61 & 1 & 2.89 & 0.26 & 0.62 \\
\hline Error & 9 & 1.42 & & & 9 & 11.1 & & \\
\hline Result & \multicolumn{4}{|c|}{$G<T$, Dry $=$ Wet } & \multicolumn{4}{|c|}{$G=T$, Dry $=$ Wet } \\
\hline \multicolumn{9}{|c|}{ Benthic microalgae } \\
\hline Site & 1 & 21.1 & 649 & $<0.001 *$ & 1 & 211 & 2925 & $<0.001 *$ \\
\hline Season & 1 & 7.26 & 223 & $<0.001 *$ & 1 & 2.65 & 36.6 & $0.001 *$ \\
\hline Site $\times$ season & 1 & 27.2 & 838 & $<0.001 *$ & 1 & 0.001 & 0.01 & 0.93 \\
\hline Error & 6 & 0.03 & & & 6 & 0.07 & & \\
\hline Result & \multicolumn{4}{|c|}{$G<T$ in the wet season, Dry $>$ Wet in $G$, Dry $<$ Wet in $T$} & \multicolumn{3}{|c|}{$G<T$, Dry $<$ Wet } & \\
\hline \multicolumn{9}{|l|}{ SPOM } \\
\hline Site & 1 & 28.2 & 87.7 & $0.001^{*}$ & 1 & 52.1 & 21.6 & $0.01^{*}$ \\
\hline Season & 1 & 21.7 & 67.4 & $0.001 *$ & 1 & 0.08 & 0.09 & 0.78 \\
\hline Site $\times$ season & 1 & 1.28 & 3.99 & 0.12 & 1 & 0.43 & 0.19 & 0.68 \\
\hline Error & 4 & 0.32 & & & 4 & 2.31 & & \\
\hline Result & \multicolumn{4}{|c|}{$G<T$, Dry $>$ Wet } & \multicolumn{4}{|c|}{$G<T$, Dry $=$ Wet } \\
\hline \multicolumn{9}{|c|}{ Liza macrolepis } \\
\hline Site & 1 & 189 & 24.1 & $<0.001^{*}$ & 1 & 1186 & 214 & $<0.001 *$ \\
\hline Season & 1 & 8.79 & 1.12 & 0.30 & 1 & 17.3 & 3.14 & 0.09 \\
\hline Site $\times$ season & 1 & 22.6 & 2.88 & 0.10 & 1 & 22.5 & 4.07 & $0.05^{*}$ \\
\hline Error & 38 & 7.85 & & & 38 & 5.52 & & \\
\hline Result & \multicolumn{4}{|c|}{$G<T$, Dry $=$ Wet } & \multicolumn{4}{|c|}{$G<T$ in both seasons, Dry $>$ Wet in $G$} \\
\hline
\end{tabular}

mangroves with abundant vascular plants, the contribution of vascular plants to the volume of the stomach content was high and reached $>40 \%$ in the dry season. In the more productive Tapong Bay (Lin et al., 2006), consumed items in the stomach contents were more diverse than those observed in the mangroves. In the lagoon densely covered by thousands of oyster-culture pens, the contribution of benthic microalgae and macroalgal periphyton to the volume of the stomach content reached $30 \%$. Although the contribution to the volume of

Table 5

Summary of $\delta^{13} \mathrm{C}(\%)$ and $\delta^{15} \mathrm{~N}(\%)$ of the dominant detritivorous fish collected in the Guandu mangroves. Means $\pm \mathrm{SE}$ and the individual number measured $(n)$ are shown below

\begin{tabular}{llll}
\hline Season & Fish species & $\delta^{13} \mathrm{C}(\%)$ & $\delta^{15} \mathrm{~N}(\% \mathrm{o})$ \\
\hline Dry & Liza macrolepis & & \\
& $38.0 \pm 2.0 \mathrm{~mm}(2)$ & $-18.7 \pm 0.2$ & $8.5 \pm 0.9$ \\
& $63.0 \pm 6.5 \mathrm{~mm} \mathrm{(3)}$ & $-19.6 \pm 0.3$ & $2.3 \pm 0.6$ \\
& Oreochromis hybrid & & \\
$95 \mathrm{~mm}(1)$ & -21.5 & 4.7
\end{tabular}

Wet Liza macrolepis

\begin{tabular}{lll}
$37.5 \pm 1.3 \mathrm{~mm}(2)$ & $-22.2 \pm 0.1$ & $1.7 \pm 0.3$ \\
$46.5 \pm 0.5 \mathrm{~mm}(2)$ & $-21.7 \pm 0.2$ & $1.8 \pm 0.3$ \\
$55.0 \pm 0.0 \mathrm{~mm}(2)$ & $-22.1 \pm 0.2$ & $1.2 \pm 0.7$ \\
Oreochromis hybrid & & \\
$56.0 \pm 3.8 \mathrm{~mm} \mathrm{(3)}$ & $-21.6 \pm 0.4$ & $5.8 \pm 0.1$ \\
\hline
\end{tabular}

the stomach content was $<5 \%$, benthic invertebrates were observed in $34 \%$ of the stomach contents taken in Tapong Bay. Deegan and Garritt (1997) indicated that estuarine consumers tend to utilize organic sources produced in the same region in which they reside. Hence, the spatial heterogeneity in stomach contents of mullet may be attributable to the fact that the mullet examined in previous studies were taken from different habitat types. Despite this, the volume of organic detritus always contributed $>50 \%$ of the stomach content of L. macrolepis in the two distinct habitats (Table 1). Our results suggest that the large-scale mullet are detritivores.

Despite the diverse diets and the distinct consumed items between Tapong Bay and the Guandu mangroves, $\delta^{15} \mathrm{~N}$ values of Liza macrolepis and other dominant detritivorous fish in these two habitats indicated that these fish are feeding approximately one trophic level above primary producers. Joint analyses of stomach contents and $\delta^{13} \mathrm{C}$ values demonstrated that the assimilated food of these fish taken from the two different habitats was benthic algae and corresponded to the dominant taxa in which they reside (Figs. 2 and 3). In the Guandu mangroves, L. macrolepis assimilated mainly benthic microalgae on sediments, whereas in Tapong Bay, microalgal and macroalgal periphyton on oyster-culture pens were the most important food sources. In mangrove creeks such as the Guandu mangroves, the availability of organic carbon from mangroves is often high (Rezende et al., 1990). The stomach contents of L. macrolepis in the mangroves also showed a high proportion 
Table 6

Summary of $\delta^{13} \mathrm{C}(\%)$ and $\delta^{15} \mathrm{~N}(\%)$ of the dominant detritivorous fish collected in Tapong Bay. Means $\pm \mathrm{SE}$ and the individual number measured $(n)$ are shown below

\begin{tabular}{|c|c|c|c|}
\hline Season & Fish species & $\delta^{13} \mathrm{C}(\%)$ & $\delta^{15} \mathrm{~N}(\%)$ \\
\hline \multirow{15}{*}{ Dry } & \multicolumn{3}{|l|}{ Liza macrolepis } \\
\hline & $92.0 \pm 2.3 \mathrm{~mm}(5)$ & $-11.9 \pm 0.3$ & $17.5 \pm 0.1$ \\
\hline & $156.3 \pm 3.5 \mathrm{~mm}(3)$ & $-21.2 \pm 0.6$ & $15.3 \pm 0.1$ \\
\hline & $209.5 \pm 2.5 \mathrm{~mm}(2)$ & $-15.2 \pm 0.1$ & $14.2 \pm 0.1$ \\
\hline & $242 \mathrm{~mm}(1)$ & -23.1 & 6.9 \\
\hline & \multicolumn{3}{|c|}{ Pomacentrus taeniometopon } \\
\hline & $91.7 \pm 1.8 \mathrm{~mm}(3)$ & $-15.2 \pm 0.1$ & $13.3 \pm 0.2$ \\
\hline & \multicolumn{3}{|l|}{ Scarus ghobban } \\
\hline & $179.0 \pm 26.0 \mathrm{~mm}(2)$ & $-16.0 \pm 0.1$ & $12.5 \pm 0.2$ \\
\hline & \multicolumn{3}{|l|}{ Scatophagus argus } \\
\hline & $110.0 \pm 10.0 \mathrm{~mm}(2)$ & $-16.9 \pm 1.1$ & $12.6 \pm 0.5$ \\
\hline & \multicolumn{3}{|l|}{ Siganus guttatus } \\
\hline & $119.3 \pm 2.6 \mathrm{~mm}(3)$ & $-13.0 \pm 1.6$ & $14.6 \pm 0.9$ \\
\hline & \multicolumn{3}{|l|}{ Valamugil cunnesius } \\
\hline & $184.3 \pm 6.4 \mathrm{~mm} \mathrm{(3)}$ & $-13.8 \pm 1.2$ & $14.1 \pm 0.6$ \\
\hline \multirow[t]{10}{*}{ Wet } & \multicolumn{3}{|l|}{ Liza macrolepis } \\
\hline & $60.0 \pm 2.9 \mathrm{~mm}(3)$ & $-14.8 \pm 0.5$ & $17.1 \pm 0.1$ \\
\hline & $66.0 \pm 0.0 \mathrm{~mm} \mathrm{(2)}$ & $-19.1 \pm 0.2$ & $14.1 \pm 0.4$ \\
\hline & $77.5 \pm 0.5 \mathrm{~mm}(2)$ & $-15.2 \pm 0.7$ & $13.7 \pm 0.1$ \\
\hline & $92.5 \pm 2.5 \mathrm{~mm}(2)$ & $-14.5 \pm 0.7$ & $17.4 \pm 0.1$ \\
\hline & $98.0 \pm 6.0 \mathrm{~mm}(2)$ & $-15.2 \pm 0.4$ & $12.9 \pm 0.7$ \\
\hline & $107.5 \pm 0.5 \mathrm{~mm}(2)$ & $-14.8 \pm 1.0$ & $13.5 \pm 0.5$ \\
\hline & $152.5 \pm 2.5 \mathrm{~mm}(2)$ & $-12.2 \pm 0.8$ & $17.8 \pm 0.1$ \\
\hline & $173.0 \pm 0.0 \mathrm{~mm}(2)$ & $-16.8 \pm 0.5$ & $16.4 \pm 0.2$ \\
\hline & $211.3 \pm 6.8 \mathrm{~mm}(3)$ & $-15.8 \pm 0.5$ & $16.0 \pm 0.1$ \\
\hline
\end{tabular}

of vascular plants. However, our results of stable isotope analyses demonstrated that vascular plants were little assimilated and utilized by the large-scale mullet. The reason for the relatively low proportion of algae observed in the stomach content might be attributable to the fast digestion rates. Softer and more easily digested items, such as algae, might persist in the stomach for much less time than refractory macrophyte detritus. The organic detritus most often occurring in the stomach contents was likely unidentified algal detritus and/or refractory food which is difficult to digest.

In Tapong Bay, high nutrient loadings and long water residence times (up to $24 \mathrm{~d}$ ) in the lagoon stimulate the growth and accumulation of phytoplankton and periphyton on oyster-culture pens. The abundance and productivity of phytoplankton and periphyton in the lagoon were higher than those recorded in most estuaries and coastal lagoons (Lin and Hung, 2004). The relative contribution of phytoplankton to system productivity and biomass was much more important than that of periphyton in the lagoon. Periphyton biomass might exceed that of phytoplankton only in winter and spring when periphyton bloom (Lin et al., 2005). The high chlorophyll $a$ contents (mean: $7.1 \mathrm{mg} \mathrm{m}^{-3}$, Su et al., 2004) and low $C: N$ ratios (mean: 7.6, Hung and Hung, 2003) were indicative of phytoplankton-rich SPOM (c.f. Cloern et al., 2002). Despite the dominance of phytoplankton in Tapong Bay, joint analyses of stomach contents and stable isotopes revealed that
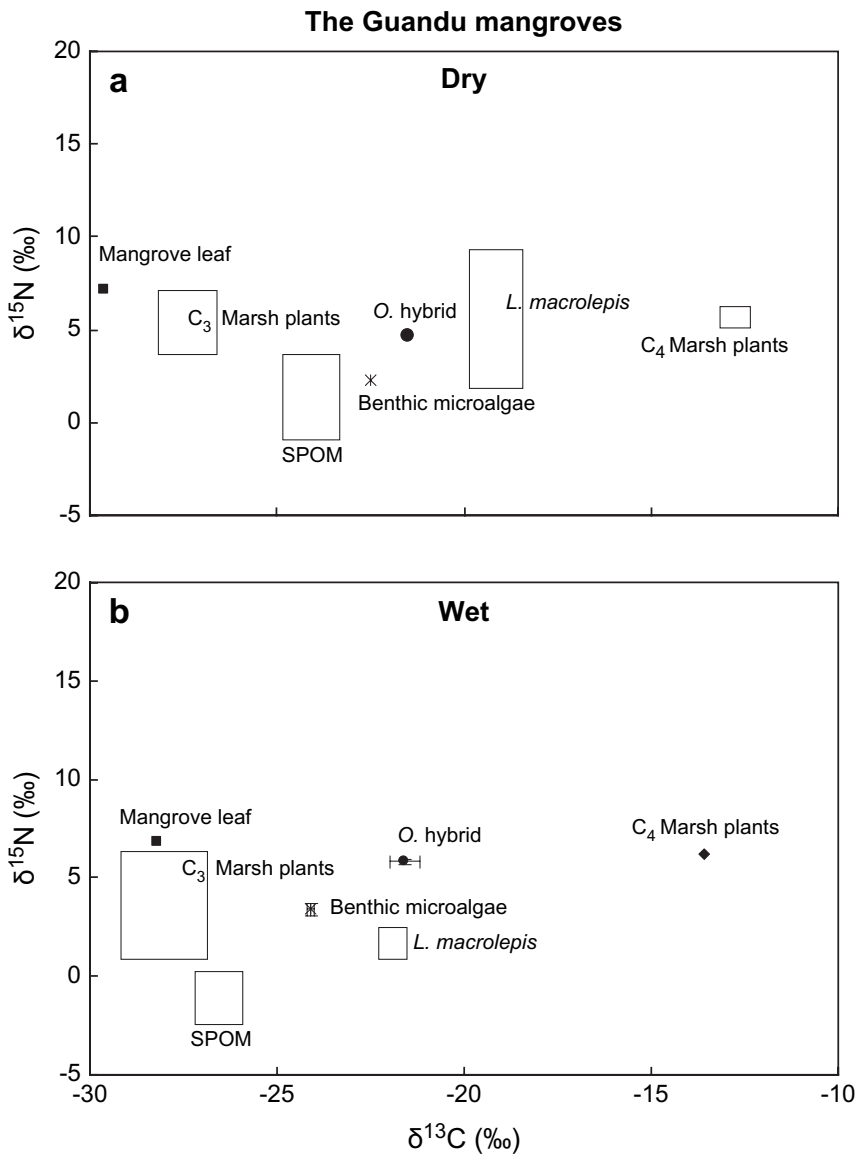

Fig. 3. $\delta^{15} \mathrm{~N}$ vs. $\delta^{13} \mathrm{C}$ of food sources and dominant detritivorous fish collected from the Guandu mangroves in the dry (a) and wet (b) seasons. Boxes indicate ranges.

SPOM were of minor importance in the food sources of L. macrolepis in the lagoon, regardless of season. Sobczak et al. (2002) found that bioavailable POM derived primarily from internal phytoplankton production was the dominant food supply to the food web in a temperate estuary. However, our results suggest that in Tapong Bay, there is not a tight coupling between pelagic primary production and the food sources of dominant detritivorous fish. In our opinion, a shift in the food chain from phytoplankton-grazing to periphytongrazing organisms has likely occurred in the tropical lagoon. While man-made aquaculture structures were being added to Tapong Bay, periphyton blooms on the introduced substratum might have altered the trophic pathways through which organic matter is transferred within the food web.

\section{Conclusions}

Despite the diverse diets and the distinct consumed items of the large-scale mullet Liza macrolepis between Tapong Bay and the Guandu mangroves, the volume of organic detritus always contributed $>50 \%$ of the stomach content, suggesting that they are detritivores. However, joint analyses of stomach contents and stable isotopes indicated that benthic microalgae on sediments were the most important assimilated food for the 
Tapong Bay
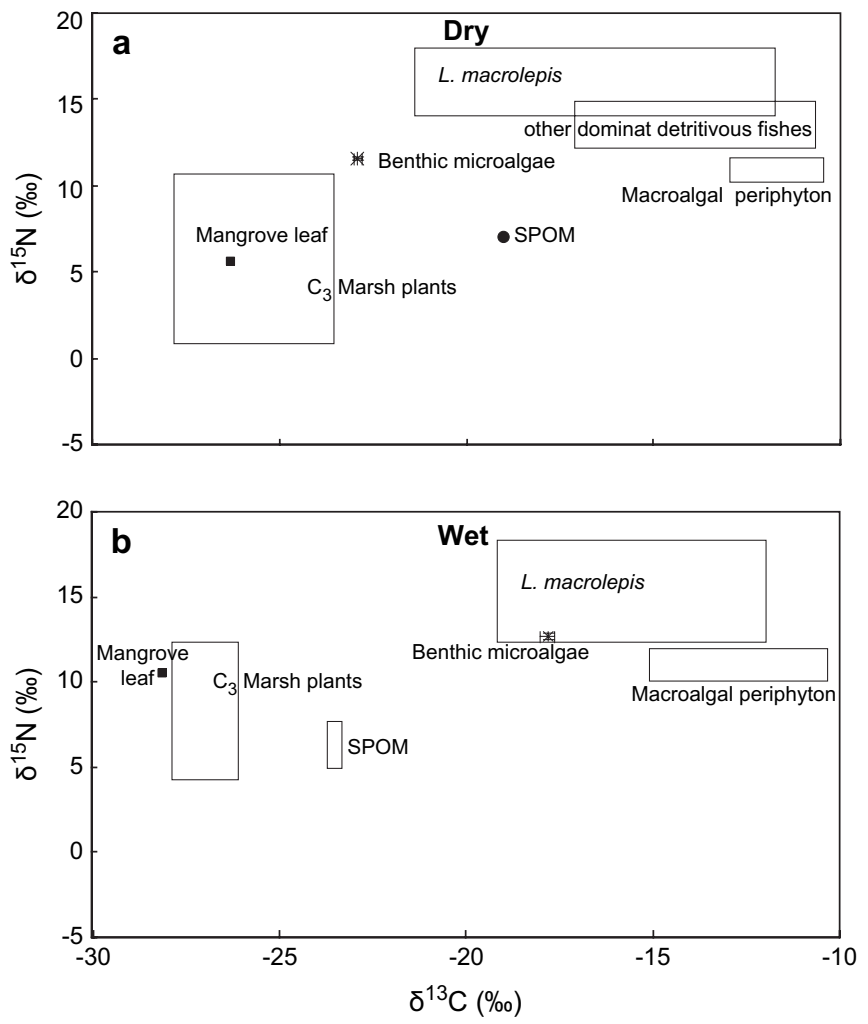

Fig. 4. $\delta^{15} \mathrm{~N}$ vs. $\delta^{13} \mathrm{C}$ of food sources and dominant detritivorous fish collected from Tapong Bay in the dry (a) and wet (b) seasons. Boxes indicate ranges.

dominant detritivorous fish in the mangroves, whereas a greater reliance on microalgal and macroalgal periphyton on oysterculture pens was observed in the tropical lagoon. Mangrove and marsh plants and phytoplankton, which are mostly locally produced within each habitat, respectively, were of minor importance in the assimilated food.

\section{Acknowledgements}

This study was supported by the National Science Council under grant number NSC89-2321-B-005-313. The authors thank Dr. Kwang-Tsao Shao and Dr. Hwey-Lian Hsieh at Research Center for Biodiversity, Academia Sinica for their help in collecting fish specimens and sample processing.

\section{References}

Ben-David, M., Flynn, R.W., Schell, D.M., 1997. Annual and seasonal changes in diets of martens: evidence from stable isotope analysis. Oecologia 111, 280-291.

Bligh, E.G., Dyer, W.J., 1959. A rapid method of total lipid extraction and purification. Canadian Journal of Biochemistry and Physiology 37, 911-917.

Boutton, T.W., 1991. Stable carbon isotope ratios of natural material: I. Sample preparation and mass spectrometric analysis. In: Coleman, D.C., Fry, B. (Eds.), Carbon Isotope Techniques. Academic Press, New York, pp. 155-171.

Chan, E.H., Chua, T.E., 1979. The food and feeding habits of greenback grey mullet, Liza subviridis (Valenciennes), from different habitats and at various stages of growth. Journal of Fish Biology 15, 165-171.
Clarke, K.R., Warwick, R.M., 1994. Changes in Marine Communities: An Approach to Statistical Analysis and Interpretation. Natural Environment Research Council, Plymouth, UK, 144 pp.

Clarke, K.R., Gorley, R.N., 2001. PRIMER v5: User Manual/Tutorial. PRIMER-E, Plymouth, UK, 91 pp.

Cloern, J.E., Canuel, E.A., Harris, D., 2002. Stable carbon and nitrogen isotope composition of aquatic and terrestrial plants of the San Francisco Bay estuarine system. Limnology and Oceanography 47, 713-729.

Costanzo, S.D., O’Donohue, M., Dennison, W.C., 2003. Assessing the seasonal influence of sewage and agricultural nutrient inputs in a subtropical river estuary. Estuaries 26, 857-865.

Darnell, R.M., 1961. Tropical spectrum of an estuarine community, based on studies of lake Pontchartrain, Louisiana. Ecology 42, 553-568.

Deegan, L.A., Garritt, R.H., 1997. Evidence for spatial variability in estuarine food webs. Marine Ecology Progress Series 147, 31-47.

DeNiro, M.J., Epstein, S., 1978. Influence of diet on the distribution of carbon isotopes in animals. Geochimica et Cosmochimica Acta 42, 495-506.

Farquhar, G.D., Hubick, K.T., Condon, A.G., Richard, R.A., 1989. Carbon isotope fractionation and plant water-use efficiency. In: Rundel, P.W., Ehleringer, J.R., Nagy, K.A. (Eds.), Stable Isotopes in Ecological Research. Springer Verlag, Berlin, pp. 21-41.

Finlay, J.C., Khandwala, S., Power, M.E., 2002. Spatial scales of carbon flow in a river food web. Ecology 83, 1845-1859.

Froese, R., Pauly, D., 2006. FishBase. World Wide Web electronic publication. Avaialble from: <www.fishbase.org $>$. Version (03/2006).

Fry, B., 1999. Using stable isotopes to monitor watershed influences on aquatic trophodynamics. Canadian Journal of Fisheries and Aquatic Sciences 56, 2167-2171.

Fry, B., Sherr, E.B., 1984. $\delta^{13} \mathrm{C}$ measurements as indicators of carbon flow in marine and freshwater ecosystems. Contributions in Marine Science 27, $13-47$.

Gonfiantini, R., Stichler, W., Rozanski, K., 1995. Standards and intercomparison materials distributed by the international atomic energy agency for stable isotope measurements. In: References and Intercomparison Materials for Stable Isotopes of Light Elements. IAEA, Vienna, pp. 13-29 (IAEA-TECDOC-825).

Hsieh, H.-L., Kao, W.-Y., Chen, C.-P., Liu, P.-J., 2000. Detrital flows through the feeding pathway of the oyster (Crassostrea gigas) in a tropical shallow lagoon: $\delta^{13} \mathrm{C}$ signals. Marine Biology 136, 677-684.

Hughes, E.H., Sherr, E.B., 1983. Subtidal food webs in a Georgia estuary: $\delta^{13} \mathrm{C}$ analysis. Journal of Experimental Marine Biology and Ecology 67, $227-242$.

Hung, J.-J., Hung, P.-Y., 2003. Carbon and nutrient dynamics in a hypertrophic lagoon in southwestern Taiwan. Journal of Marine System 42, 97-114.

Hyslop, E.L., 1980. Stomach contents analysis - a review of methods and their application. Journal of Fish Biology 17, 411-429.

Jones, A.B., O’Donohue, M.J., Udy, J., Dennison, W.C.D., 2001. Assessing ecological impacts of shrimp and sewage effluent: biological indicators with standard water quality analyses. Estuarine, Coastal and Shelf Science 52, 91-109.

Kamer, K., Boyl, K.A., Fong, P., 2001. Macroalgal bloom dynamics in a highly eutrophic southern California estuary. Estuaries 24, 623-635.

Kling, G.W., Fry, B., O'Brien, W.J., 1992. Stable isotopes and planktonic trophic structure in Arctic lakes. Ecology 73, 561-566.

Kuo, S.-R., Lin, H.-J., Shao, K.-T., 2001. Seasonal changes in abundance and composition of the fish assemblage in Chiku Lagoon, Southwestern Taiwan. Bulletin of Marine Science 68, 85-99.

Kwak, T.J., Zedler, J.B., 1997. Food web analysis of southern California coastal wetlands using multiple stable isotopes. Oecologia 110, 262-277.

Lin, H.-J., Dai, X.-X., Shao, K.-T., Su, H.-M., Lo, W.-T., Hsieh, H.-L., Fang, L.-S., Hung, J.-J., 2006. Trophic structure and functioning in a eutrophic and poorly-flushed lagoon in southern Taiwan. Marine Environmental Research 62, 61-82.

Lin, H.-J., Wang, T.-C., Su, H.-M., Hung, J.-J., 2005. Relative importance of phytoplankton and periphyton on oyster-culture pens in a eutrophic tropical lagoon. Aquaculture 243, 279-290.

Lin, H.-J., Hung, J.-J., 2004. Factors affecting macroalgal distribution in a eutrophic tropical lagoon in Taiwan. Marine Biology 144, 653-664. 
Lin, H.-J., Shao, K.-T., Chiou, W.-L., Maa, C.-J.W., Hsieh, H.-L., Wu, W.-L., Severinghaus, L.L., Wang, Y.-T., 2003. Biotic communities of freshwater marshes and mangroves in relation to saltwater incursions: implications for wetland regulation. Biodiversity and Conservation 12, 647-665.

Lin, H.-J., Hung, J.-J., Shao, K.-T., Kuo, F., 2001. Trophic functioning and nutrient flux of a highly productive tropical lagoon. Oecologia 129, 395-406.

Lin, H.-J., Shao, K.-T., 1999. Seasonal and diet changes in a subtropical mangrove fish assemblage. Bulletin of Marine Science 65, 775-794.

Mann, K.H., 1988. Production and use of detritus in various freshwater, estuarine, and coastal marine ecosystems. Limnology and Oceanography 33, 910-930.

McClelland, J.W., Valiela, I., Michener, R.H., 1997. Nitrogen-stable isotope signatures in estuarine food webs: a record of increasing urbanization in coastal watersheds. Limnology and Oceanography 42, 930-937.

Minagawa, M., Wada, E., 1984. Stepwise enrichment of ${ }^{15} \mathrm{~N}$ along food chains: further evidence and the relation between $\delta^{15} \mathrm{~N}$ and animal age. Geochimica et Cosmochimica Acta 48, 1135-1140.

Nixon, S.W., Oviatt, C.A., Frithsen, J., Sullivan, B., 1986. Nutrients and the productivity of estuarine and coastal ecosystems. Journal of Limnological Society of Southern Africa 12, 43-71.

Odum, W.E., 1970. Utilization of the direct grazing and plant detritus food chains by the striped mullet Mugil cephalus. In: Steele, J.H. (Ed.), Marine Food Chains. Oliver \& Boyd, Edinburgh, pp. 222-240.

Peterson, B., 1999. Stable isotopes as tracers of organic matter input and transfer in benthic food webs: a review. Acta oecologica 20, 479-487.

Pinnegar, J.K., Polunin, V.C., 1999. Differential fractionation of $\delta 13 \mathrm{C}$ and $\delta 15 \mathrm{~N}$ among fish tissues: implications for the study of trophic interactions. Functional Ecology 13, 225-231.

Post, D.M., 2002. Using stable isotopes to estimate trophic position: models, methods, and assumptions. Ecology 83, 703-718.

Rezende, C.E., Lacerda, L.D., Ovalle, A.R.C., Silva, C.A.R., Martinelli, L.A., 1990. Nature of POC transport in a mangrove ecosystem: a carbon stable isotopic study. Estuarine, Coastal and Shelf Science 30, 641-645.

Riera, P., Richard, P., 1996. Isotopic determination of food sources of Crassostrea gigas along a trophic gradient in the estuarine bay of MarennesOléron. Estuarine, Coastal and Shelf Science 42, 347-360.
Rodelli, M.R., Gearing, J.N., Gearing, P.J., Marshall, N., Sasekumar, A., 1984. Stable isotope ratio as a tracer of mangrove carbon in Malaysian ecosystems. Oecologia 61, 326-333.

Round, F.E., Crawford, R.M., Mann, D.G., 1990. Diatoms. Cambridge University Press, Cambridge, 747 pp.

Sobczak, W.V., Cloern, J.E., Jassby, A.D., Müller-Solger, A.B., 2002. Bioavailability of organic matter in a highly disturbed estuary: the role of detrital and algal resources. Proceedings of the National Academy of Sciences of the United States of America 99, 8101-8105.

Stephenson, R.L., Tan, F.C., Mann, K.H., 1984. Stable carbon isotope variability in marine macrophytes and its implications for food web studies. Marine Biology 81, 223-230.

Stribling, J.M., Cornwell, J.C., 1997. Identification of important primary producers in a Chesapeake Bay tidal creek system using stable isotopes of carbon and sulfur. Estuaries 20, 77-85.

Su, H.M., Lin, H.J., Hung, J.J., 2004. Effects of tidal flushing on phytoplankton in a eutrophic tropical lagoon in Taiwan. Estuarine, Coastal and Shelf Science 61, 739-750.

Sullivan, M.J., Moncreiff, C.A., 1990. Edaphic algae are an important component of salt marsh food-webs: evidence from multiple stable isotope analyses. Marine Ecology Progress Series 62, 149-159.

Sweeting, C.J., Polunin, N.V.C., Jennings, S., 2006. Effects of chemical lipid extraction and arithmetic lipid correction on stable isotope ratios of fish tissues. Rapid Communications in Mass Spectrometry 20, 595-601.

Wainright, S.C., Weinstein, M.P., Able, K.W., Currin, C.A., 2000. Relative importance of benthic microalgae, phytoplankton, the detritus of smooth cordgrass Spartina alterniflora and common reed Phragmites australis to brackish-marsh food webs. Marine Ecology Progress Series 200, 77-91.

Yáñez-Arancibia, A., 1976. Observaciones sobre Mugil curema Valenciennes, en areas naturales de crianza, Mexico. Alimentacion, madurez, crecimento y relaciones ecologicas. Anales del Centro de Ciencias del Mar y Limnologia. Universidad Nacional Autónoma de México 3, 93-124. 